\title{
Evidence of high inbreeding in a population of the endangered giant anteater, Myrmecophaga tridactyla (Myrmecophagidae), from Emas National Park, Brazil
}

\author{
Rosane G. Collevatti ${ }^{1}$, Kelly C.E. Leite ${ }^{1}$, Guilherme H.B. de Miranda ${ }^{2}$ and Flavio H.G. Rodrigues ${ }^{3}$ \\ ${ }^{1}$ Universidade Católica de Brasília, Brasília, DF, Brazil. \\ ${ }^{2}$ Departamento de Polícia Federal, Diretoria Técnico-Científica, Instituto Nacional de Criminalística, \\ Brasilia, DF, Brazil. \\ ${ }^{3}$ Associação Pró-Carnívoros, Atibaia, SP, Brazil.
}

\begin{abstract}
We report the genetic structure, relatedness and mating structure of a population of the endangered giant anteater Myrmecophaga tridactyla Linnaeus, 1758 in the Emas National Park, Brazil, based on variability at five microsatellite loci. Additionally, we addressed the hypothesis that the M. tridactyla population studied has low levels of polymorphism and high levels of inbreeding and relatedness and that animals with overlapping home range are highly related. All five microsatellite loci displayed low levels of polymorphism and of expected and observed heterozygosity. The low level of polymorphism and high inbreeding showed by the population studied may be the outcome of high mortality and reduction in population size due to recurrent fire events in the Emas National Park, as reported in 1994. The reduction in population size may have led to a higher frequency of mating between closely related animals, augmented by the isolation of the population in the park because of the expansion of agricultural land and fragmentation of the Cerrado environment. The natural history of $M$. tridactyla and the phylopatric (sex-biased dispersal) behavior of females should increase the effects of isolation and bottlenecking, decreasing gene flow and increasing inbreeding. However, the low levels of polymorphism found in this population may simply be due to the natural history and evolution of $M$. tridactyla as reported for other species. The genetic structure and dynamics of this population needs to be investigated more profoundly in order to provide sound data for the design of conservation strategies for $M$. tridactyla in the Emas National Park.
\end{abstract}

Key words: Cerrado, conservation, microsatellites, phylopatry, relatedness.

Received: November 7, 2005; Accepted: July 21, 2006.

\section{Introduction}

The deleterious effects of inbreeding have been recognized for many years (Darwin, 1876) and the effects of inbreeding in population genetic structure has been extensively discussed by Sewall Wright (Wright, 1917, 1921, 1931, 1937, 1946, 1951 and 1965) who developed theoretical support and statistical methods to measure the extend of inbreeding in populations. From a conservation viewpoint, the effects of inbreeding and the loss of genetic diversity in small and isolated population have been of major concern because of their deleterious effects on population viability(Charlesworth and Charlesworth, 1987; Frankham,

Send correspondence to Rosane Garcia Collevatti. Pós-Graduação em Ciências Genômicas e Biotecnologia, Universidade Católica de Brasília, SGAN 916, Mod. B, Asa Norte, 70790-160 Brasília, DF, Brazil. E-mail: rosanegc@pos.ucb.br.

${ }^{3}$ Present address: Departamento de Ecologia, Universidade Federal de Minas Gerais, 31270-901 Belo Horizonte, MG, Brazil.
1995, 2003; Frankham et al., 2002; Reed et al., 2003; Reed and Frankham, 2003; Reed, 2005). Besides theoretical predictions, there is clear evidence that inbreeding and the loss of genetic diversity adversely affects wild and captive populations, reducing reproductive success and survival and increasing the risk of extinction (Ralls et al., 1986, 1988; Saccheri et al., 1998; Westemeier et al., 1998; Coltman et al., 1998; Crnokrak and Roff, 1999; Eldridge et al., 1999; Dietz et al., 2000).

Habitat fragmentation is one of the most important threats to long term species viability (Gilpin and Soulé, 1986; Frankham 1995, 2003; Laurance \& Bierregaard, 1997). Habitat loss may lead to a decrease in population size and isolation among remnant populations. During such process, genetic variability may be lost through genetic bottlenecks, while subsequently founder effects, genetic drift and restricted gene flow may increase population genetic isolation and divergence (Terborgh and Winter, 1980; Gil- 
pin and Soulé, 1986). These genetic effects, added to the possible enhancement of inbreeding, may lead to fixation of deleterious alleles and endanger species persistence in population fragments and jeopardize their conservation, especially in populations which were originally large and widely distributed (Gilpin and Soulé, 1986; Frankham et al., 2002).

Fragmentation of tropical ecosystems because of harvesting for wood products or agricultural expansion has been changing the original landscape to a mosaic of remnant habitats surrounded by unfavorable environments. In Brazil, the Cerrado covers nearly $22 \%$ of Brazil (2 million $\mathrm{km}^{2}$ ) and is characterized by very heterogeneous vegetation, ranging from tropical broadleaf woodlands to scrublands, containing nearly 160,000 species, including plants, animals and fungi (Ratter et al., 1997). The Brazilian Cerrado biome is highly threatened because of the rapid and intensive expansion of agricultural land in Central Brazil (Ratter et al., 1997), which results in "islands" of wild habitat surrounded by an "ocean" of crops and jeopardizes species viability.

The giant anteater Myrmecophaga tridactyla Linnaeus, 1758 (Xenarthra: Myrmecophagidae) is the largest species of anteater in the world and widely distributed in Central and South America but despite its wide distribution $M$. tridactyla is now extinct in many areas of its original distribution. In Brazil, M. tridactyla populations are restricted to national parks and other reserves, with the largest populations being reported in Emas National Park and Serra da Canastra National Park in the Cerrado biome of Central-Western Brazil (Miranda, 2004). Because of its vulnerability, $M$. tridactyla is in the World Conservation Union (IUCN) Red List as vulnerable (IUCN, 2004). Besides habitat loss, M. tridactyla may be vulnerable to extinction due to some characteristics of its natural history, such as slow movement, solitary habit, a long gestation with one offspring and a long gestation interval of nine months (Eisenberg and Redford, 1999; Nowak, 1999).

In this paper we report the genetic structure, relatedness and mating structure of a population of M. tridactyla from Emas National Park and discuss the potential consequences for conservation. Our working hypothesis was that the population has low levels of polymorphism and high levels of inbreeding and relatedness, and that individuals with an overlapping home range are highly related. Genetic data was generated using microsatellite markers, one of the most powerful molecular markers for estimating genetic parameters and describing population genetic structure and parentage (Goldstein and Schlotterer, 1999).

\section{Material and Methods}

\section{Populations, sampling and DNA extraction}

The study was conducted in Emas National Park (ENP; $18^{\circ} 15^{\prime} 50^{\prime \prime} \mathrm{S}, 52^{\circ} 53^{\prime} 33^{\prime \prime} \mathrm{W}$ ) which covers 131,868 ha in Central Western Brazil and is one of the largest National Park in the Cerrado biome. The population size of $M$. tridactyla was estimated based on line transect, aerial survey and mark-recapture (Miranda, 2004). Because the overall population density of $M$. tridactyla in ENP was only 0.23 animals per square $\mathrm{km}$ we sampled the center and the periphery of the park where the population density was higher. All the $M$. tridactyla specimens $(\mathrm{n}=27)$ sighted in ENP during the investigation were included in the study, some were dispersed at the park periphery and others grouped into two subpopulations (SPI and SPII) as shown in Figure 1. We captured 16 M. tridactyla (SPI, Figure 1) in the center of the park and fitted them with radio transmitters. The animals were categorized according to their ages as: adult males (specimens $\mathrm{TBC} 02$ to $\mathrm{TBC} 06, \mathrm{TBC} 12$, TBC13, TBC15 and $\mathrm{TBC} 17$ ); adult females (TBC07, TBC09, TBC16 and TBC20); a sub-adult male (TBC08); and a juvenile female (TBC11). These animals were monitored for 15 months during 2002 and 2003 to study the detailed structure of the population and to estimate their home range (Miranda, 2004). Another 11 M. tridactyla were captured at the periphery of the park (Figure 1) and their ranges mapped using the global positing system (GPS). Seven specimens (SPII) of this set grouped at the same locality at the periphery and outside the park and were categorized according to their ages as adult males (TBC21, TBC22, $\mathrm{TBC} 26$ and $\mathrm{TBC} 28)$ and adult females (TBC29, TBC30 and $\mathrm{TBC} 31$ ), while a further four adult male $M$. tridactyla (TBC01, ТВC23, ТBC24 and TBC25) were sparsely distributed at the peripheral area of the park. A single male (TBC01) was fitted with a radio transmitter but the signal was lost after few days and this animal was not included in the home range study but was included in the microsatellite analysis. After sexing, a vacutainer was used to collect a small blood sample from each animal for DNA extraction and genetic analysis. Total DNA was extracted with QIAamp Blood Kit (QUIAGEN, NL), following the manufacture instructions.

For sampling, the animals were capture and immobilized with darts using $9.56 \mathrm{mg} \mathrm{kg}^{-1}$ of Ketamin and $1.6 \mathrm{mg} \mathrm{kg}^{-1}$ of Xylazine, a sufficient amount (based on estimated body weight) to maintain the animal immobilized but conscious for 30-45 min. The individuals were manipulated following ASM (American Society of Mammalogists)guidelines.

\section{Genetic analysis}

Five M. tridactyla (Mtri) microsatellite loci (MtriUSP04, MtriUSP07, MtriUSP11, MtriUSP13) MtriUSP17) previously developed by Garcia et al. (2005) were used to genotype all the animals sampled. For genotyping, microsatellite amplifications were performed in a $10 \mu \mathrm{L}$ volume containing $10.0 \mu \mathrm{M}$ of each primer, 1 unit of Tax DNA polymerase (Finedraw, BR), $200 \mu \mathrm{M}$ of each dNTP, 1X reaction buffer $(10 \mathrm{mM}$ Tris- $\mathrm{HCl}, \mathrm{pH} 8.3$, 

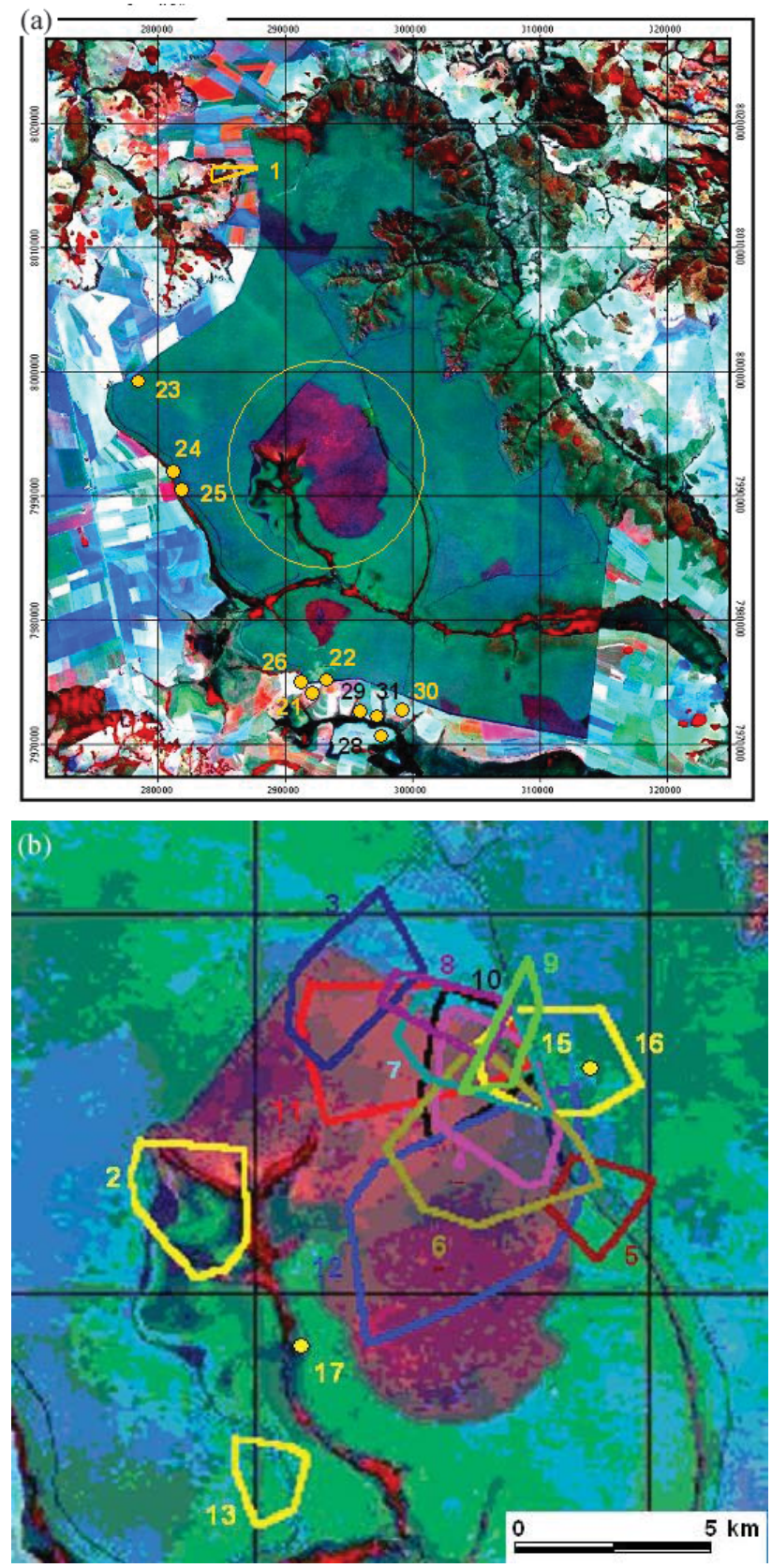

Figure 1 - LANDSAT V satellite image for 2002 of the Emas National Park, Brazil (darker area) showing the locality of the Myrmecophaga tridactyla specimens sampled. Figure $1 \mathrm{X}$ represents the center of the park circled in Figure 1a. Yellow circles represent the capture localities and polygons represent the home range. Animals in the center of the map (see detail in Figure 1X) belong to subpopulation I (SPI; specimens TBC02 to $\mathrm{TBC} 13$, and $\mathrm{TBC} 15, \mathrm{TBC} 16, \mathrm{TBC} 17$ and $\mathrm{TBC} 20)$, at the bottom of the map (a) to subpopulation II (SPII; TBC21, TBC22, TBC26, TBC28 to $\mathrm{TBC} 31)$ and at the left and upper part of the map to the peripheral group (TBC01, TBC23, TBC24, TBC25). The prefix TBC was omitted for clarity.

$50 \mathrm{mM} \mathrm{KCl}, 1.5 \mathrm{mM} \mathrm{MgCl}$ ), and $20 \mathrm{ng}$ of template DNA. Amplifications were performed using a PE9700 thermal controller (Applied Biosystems, USA) under the following conditions: $96^{\circ} \mathrm{C}$ for $2 \mathrm{~min} ; 30$ cycles of: $94^{\circ} \mathrm{C}$ for $1 \mathrm{~min}$, 55 to $62{ }^{\circ} \mathrm{C}$ for $1 \mathrm{~min}$ (according to each locus), $72{ }^{\circ} \mathrm{C}$ for
$1 \mathrm{~min}$; and $72{ }^{\circ} \mathrm{C}$ for $10 \mathrm{~min}$. The amplified products were separated on $4 \%(\mathrm{w} / \mathrm{v})$ denaturing polyacrylamide gels, stained with silver nitrate (Creste et al., 2001) and sized by comparison to a 10 bp DNA ladder standard (Invitrogen, USA). All animals were genotyped at least four times using independent PCR amplifications and polyacrylamide gels to avoid genotyping error.

\section{Statistical analysis}

Microsatellite loci were characterized for the number of alleles per locus and expected (He) and observed (Ho) heterozygosities under Hardy-Weinberg equilibrium (Nei, 1978). Inbreeding coefficients ( $f$ ), for each locus and overall loci, were also estimated (Weir and Cockerham, 1984). Analyses were performed with the FSTAT program version 2.9.3.2 (Goude, 2002) and randomization based tests with Bonferroni correction were performed generating the log-likelihood statistics $\mathrm{G}$ to test for deviation from Hardy-Weinberg expectations (Goudet et al., 1996).

To assess detailed genetic structure pairwise and mean relatedness were estimated considering the following categories: all animals sampled, all adults males and females, adult males, and adult females. These categories were also considered for relatedness analysis for subpopulations SPI and SPII. Relatedness was estimated based on the unbiased regression estimator of Lynch and Ritland (1999) using the Mark software (Ritland, 2003). Monte Carlo simulation provided estimates of relatedness variance and mean relatedness standard error when sample size was adequate. For some combinations, the Queller and Goodnight (1989) pairwise relatedness estimator was used because of small sample size. An analysis of variance (AMOVA) was performed to test for differences in relatedness between categories followed by the Tukey and Tamhane T2 (considering heterocedasticity) tests (Sokal and Rolf, 2000). The Sperman correlation was used to verify if home range overlapping was correlated to relatedness and gender (Sokal and Rolf 2000).

Genetic differentiation between subpopulations SPI and SPII was assessed by Wright's F-statistics $(F, \theta$, and $f$ : Wright, 1951) obtained from an analysis of variance of allele frequencies (Cockerham 1969). As most microsatellite mutations involve the addition or subtraction of a small number of repeat units according to a stepwise mutation model (Valdes et al. 1993; Slatkin 1995) population differentiation was also assessed by Slatkin's R RT (Slatkin 1995) obtained from an analysis of variance of allele size following Goodman (1997). The analyses were performed using the FSTAT program 2.9.3.2 (Goudet 2002). A significance test of differentiation with Bonferroni correction was performed by randomizing genotypes among samples to obtain the log-likelihood G statistics (Goudet et al. 1996). $\mathrm{R}_{\mathrm{ST}}$ is analogous to $\theta$, and may be interpreted as the correlation between allele size of different individuals in the same population (Cockerham, 1969; Weir \& Cockerham, 1984). 
To detect evidence of sex-biased dispersal (phylopatry) an assignment test was performed, as proposed by Goudet et al. (2002) and implemented in the FSTAT program 2.9.3.2 (Goudet et al. 2002) under the following assumptions: dispersal occurs at the juvenile stage before reproduction and individual animals were sampled post dispersal. The following parameters were estimated separately for both sexes, considering animals from subpopulations SPI and SPII and SPI compared with the other animals (SPII and peripherally captured animals): the inbreeding coefficient, $f$ (Weir and Cockerham, 1984); the co-ancestry coefficient, $\theta$ (Weir and Cockerham, 1984); the assignment index, AIc (Paetkau et al, 1995; Goudet et al., 2002); and the variance of the assignment index, vAIc (Goudet et al., 2002). Statistical differences between the two sexes were verified using 1,000 randomizations to assign a sex randomly to each multilocus genotype.

Maternity and paternity was assessed using a paternity assignment test (Marshall et al., 1998), considering that neither parent was known, using CERVUS 2.0 software (Marshall 2001). The analysis was first performed including all adults as candidate parents and then for SPI and SPII separately. A 10,000 cycle simulation was performed considering $100 \%$ of candidate parents sampled and loci typed plus a genotyping error of 0.01 to generate the distribution and find the critical values of $\Delta$ (difference in the logarithm of the likelihood ratios (LOD scores) between the two most-likely parents). Paternity exclusion probability of the first and second parents were estimated based on estimated allele frequencies and assuming that the first parent was assigned correctly. Paternity exclusion probability corresponds to the power with which a locus excludes an individual from being the parent of an offspring (Chakravarti and Li 1983). The combined probability of paternity exclusion $\left(P=1-\left[\Pi\left(1-P_{i}\right)\right]\right)$ was also estimated for the combined battery of loci using the CERVUS 2 program (Marshall 2001).

\section{Results}

All five microsatellite loci displayed low levels of polymorphism (Table 1). Mean expected (He) and observed (Ho) heterozygosity for all loci was $\mathrm{He}=0.073$ to 0.672 and $\mathrm{Ho}=0.000$ to 0.185 . For all loci, the observed heterozygosity was significantly lower than that expected under Hardy-Weinberg equilibrium, with the inbreeding coefficient being significantly different from zero (Table 1). Inbreeding was also high and significant for each subpopulation analyzed: $0.833(\mathrm{p}=0.01)$ for SPI and 0.999 $(\mathrm{p}=0.01)$ for SPII.

Relatedness between the animals in SPI was not significantly higher than relatedness between those in SPII or between all the $M$. tridactyla specimens sampled. Nevertheless, relatedness between females and males from SPI was significantly different from the other categories but not significantly different from each other (AMOVA, $\mathrm{F}=2.515, \mathrm{p}=0.015$, Table 2 ). Considering only the animals in SPI, but excluding TBC15, TBC17 and TBC20

Table 1 - Number of Myrmecophaga tridactyla specimens (N), total number of alleles (A), observed $(\mathrm{Ho})$ and expected $(\mathrm{He})$ heterozygosity, inbreeding coefficient $(f)$ and exclusion probability of the first (Exc1) and second (Exc2) parent for the five $M$. tridactyla microsatellite loci pooling all specimens sampled at Emas National Park, Brazil. All $f$-values were significantly different from zero at $\mathrm{p}<0.01$.

\begin{tabular}{lccccccc}
\hline Locus & $\mathrm{N}$ & $\mathrm{A}$ & $\mathrm{He}$ & $\mathrm{Ho}$ & $f$ & Exc1 & Exc2 \\
\hline MtriUSP 04 & 27 & 4 & 0.516 & 0.185 & 0.646 & 0.005 & 0.045 \\
MtriUSP 07 & 20 & 4 & 0.672 & 0.000 & 1.000 & 0.277 & 0.455 \\
MtriUSP 11 & 27 & 4 & 0.659 & 0.111 & 0.834 & 0.210 & 0.380 \\
MtriUSP 13 & 20 & 2 & 0.492 & 0.000 & 1.000 & 0.146 & 0.273 \\
MtriUSP 17 & 27 & 2 & 0.073 & 0.000 & 1.000 & 0.106 & 0.237 \\
For all loci & & & 0.482 & 0.059 & 0.879 & 0.566 & 0.821 \\
\hline
\end{tabular}

Table 2 - Mean relatedness, by category, between Myrmecophaga tridactyla specimens sampled at Emas National Park, Brazil.

\begin{tabular}{lcccc}
\hline Category $^{\#}$ (number of specimens) & Mean relatedness (r) & Standard error of ${ }^{\&}$ & Variance of r & Range of r \\
\hline All specimens (27) & $0.095^{\mathrm{a}}$ & 0.002 & 0.039 & $-0.560-0.500$ \\
All adults (25) & $0.092^{\mathrm{a}}$ & 0.002 & 0.040 & $-0.508-0.500$ \\
Adult males (18) & $-0.028^{\mathrm{a}}$ & 0.027 & 0.052 & $-0.494-0.500$ \\
Adult females (07) & $-0.219^{\mathrm{a}}$ & - & 0.408 & $-1.429-0.500$ \\
SPI (16) & $-0.009^{\mathrm{a}}$ & 0.005 & 0.016 & $-0.407-0.500$ \\
SPII (07) & $-0.103^{\mathrm{a}}$ & - & 0.190 & $-0.550-0.500$ \\
SPI adult males (12) & $0.115^{\mathrm{b}}$ & 0.002 & 0.038 & $-0.313-0.500$ \\
SPI adult females (04) & $0.111^{\mathrm{b}}$ & - & 0.092 & $-0.269-0.500$ \\
SPII adult females (03) $^{*}$ & $-0.167^{\mathrm{a}}$ & - & 0.056 & $-0.500-0.000$ \\
\hline
\end{tabular}

${ }^{\#}$ SPI = subpopulation I; SPII = subpopulation II (see Materials and Methods for details).

${ }^{\&}$ The standard error was obtained from a Monte Carlo simulation.

*Estimates of the number of specimens obtained using Queller and Goodnigh (1989) because of small sample size.

${ }^{\mathrm{a}, \mathrm{b}}$ Values in the same column followed by the same letter are not statistically different by the Tukey and Tamhane T2 tests at $\mathrm{p}>0.05$. 
whose home range could not be determined, pairwise relatedness was not correlated with overlapping home range $(p=0.693)$. Although sex was positively correlated with overlapping home range $r=0.414, p=0.004$ ) and males had a significantly higher home range overlap with females (AMOVA, $F=6.389, p=0.001$ ), males and females with an overlapping home range were not more related than the other animals $(\mathrm{p}=0.110)$. We calculated that the mean home range of M. tridactyla in ENP was $9.83 \pm 6.29 \mathrm{~km}^{2}$, with no difference between males and females $(t=0.917$, $\mathrm{p}>0.05$ ). Home range overlapping ranged from 0 to $90 \%$ (detailed data published in Miranda 2004).

Both the $\mathrm{R}_{\mathrm{ST}}$ and $\theta$ estimates showed a high and significant level of genetic differentiation between SPI and SPII $\left(\mathrm{R}_{\mathrm{ST}}=0.1517, \theta=0.168, \mathrm{p}=0.01\right)$. Additionally, $f$ and $F$ were also high and significant $(f=0.88, \mathrm{p}=0.002$; $F=0.900, \mathrm{p}=0.002$ ).

When SPI was compared to SPII or with all animals (i.e. SPII plus the peripheral animals, Table 3) the assignment test results indicated that in M. tridactyla the female is the more phylopatric sex. Significant differences between male and females were obtained for $f(\mathrm{p}=0.025$ for SPI/SPII and $\mathrm{p}=0.036$ for SPI/all animals) and the assignment index ( $p=0.036$ for SPI/SPII and $p=0.041$ for SPI/all animals), with negative assignment index values for males for both comparisons (Table 3). Although males presented higher assignment index variances they were not significantly different from the values for the females for both comparisons $(p=0.53$ for SPI/SPII and $p=0.149$ for $\mathrm{SPI} /$ all animals).

The combined probability of exclusion of the first $(0.566)$ and second $(0.821)$ parent were relatively small (Table 1), as a consequence of the low polymorphism displayed by the population studied. The critical LOD scores and critical $\Delta$ value for strict and relaxed levels (confidence $>95 \%$ and $>80 \%$, respectively) were obtained after simula- tion with all the animals sampled. For the strict level the critical $\Delta=2.16$, while for the relaxed level it was 1.20 . The expected success rate was 3\% for strict level, $16 \%$ for relaxed level and $84 \%$ when unresolved. Considering all the animals sampled, we assigned maternity to four animals with more than $95 \%$ confidence and to two animals with at the relaxed level (Table 4). For SPI only one animal could be assign maternity at the $95 \%$ confidence level and one at the $80 \%$ level (Table 4). For subpopulation SPII maternity and paternity could be assign for four animals. Nevertheless, these cases should be considered unresolved because the same animal was indicated as both an offspring and a father as a consequence of the high relatedness between animals (Table 4).

No difference in genotyping was found when animals were genotyped in at least four independent PCR amplifications and polyacrylamide gels.

\section{Discussion}

Our results indicated that the population studied presented low level of polymorphism, with a small number of alleles per locus and that all loci departed from HardyWeinberg equilibrium. Additionally, for three loci (MtriUSP11, MtriUSP13 and MtriUSP17) the number of alleles per locus found in our sample was lower than the number found by Garcia et al. (2005). This may have been due to differences in the sampling distribution between the two studies, because while our study focused on the genetic structure of one population in Emas National Park (ENP) Garcia et al. studied the polymorphism of loci and sampled only seven M. tridactyla in ENP and eight from other localities, including animals killed on roads far away from ENP.

Loci with small numbers of alleles or with a skewed frequency distribution (i.e. a few high frequency alleles) tend to show low heterozygosity (Nei 1978). Additionally, sample size may be an important factor in the accurate esti-

Table 3 - Sex-biased dispersal analysis, by category, for Myrmecophaga tridactyla sampled at Emas National Park, Brazil.

\begin{tabular}{|c|c|c|c|c|c|c|}
\hline \multirow[b]{2}{*}{$\begin{array}{l}\text { Category (number } \\
\text { of specimens) }\end{array}$} & \multirow[b]{2}{*}{$\begin{array}{l}\text { Inbreeding } \\
\text { coefficient }(f)\end{array}$} & \multirow[b]{2}{*}{$\begin{array}{c}\text { Co-ancestry } \\
\text { coefficient }(\theta)\end{array}$} & \multirow[b]{2}{*}{$\begin{array}{l}\text { Assignment } \\
\text { index (Aic) }\end{array}$} & \multirow[b]{2}{*}{$\begin{array}{c}\text { Aic variance } \\
\text { (vAIc) }\end{array}$} & \multicolumn{2}{|c|}{ Heterozygosity } \\
\hline & & & & & $\begin{array}{l}\text { Observed } \\
(\mathrm{Ho})\end{array}$ & $\begin{array}{c}\text { Expected } \\
(\mathrm{He})\end{array}$ \\
\hline \multicolumn{7}{|l|}{ SPI - SPII } \\
\hline Females (08) & $0.530^{*}$ & 0.279 & $1.126^{*}$ & 3.731 & 0.075 & 0.159 \\
\hline Males (15) & $0.916^{*}$ & 0.211 & $-0.600 *$ & 11.700 & 0.040 & 0.479 \\
\hline Overall (23) & 0.880 & 0.168 & - & - & 0.050 & 0.436 \\
\hline \multicolumn{7}{|l|}{ SPI - all specimens } \\
\hline Females (08) & $0.530^{*}$ & 0.279 & $1.313^{*}$ & 2.954 & 0.075 & 0.159 \\
\hline Males (19) & $0.893 *$ & 0.149 & $-0.553 *$ & 11.055 & 0.053 & 0.490 \\
\hline Overall (27) & 0.868 & 0.143 & - & - & 0.059 & 0.449 \\
\hline
\end{tabular}

${ }^{\#}$ SPI = subpopulation I; SPII = subpopulation II (see Materials and Methods for details).

*Female and male values are statistically different at $\mathrm{p}<0.05$. 
Table 4 - Maternity and paternity parentage assignment analysis, by category, for Myrmecophaga tridactyla sampled at Emas National Park, Brazil. All, includes all categories -SPI, SPII and Periphery.

\begin{tabular}{|c|c|c|c|c|c|c|}
\hline $\begin{array}{l}\text { Category and } \\
\text { offspring }\end{array}$ & $\begin{array}{c}\text { Potential } \\
\text { mother }\end{array}$ & $\begin{array}{l}\text { Confidence } \\
\text { interval }\end{array}$ & $\begin{array}{c}\text { Pairwise } \\
\text { relatedness (r) }\end{array}$ & $\begin{array}{l}\text { Potential } \\
\text { father }\end{array}$ & $\begin{array}{c}\text { Confidence } \\
\text { interval }\end{array}$ & $\begin{array}{c}\text { Pairwise } \\
\text { relatedness (r) }\end{array}$ \\
\hline \multicolumn{7}{|l|}{ All } \\
\hline ТВC01 & & & & ТВC02 & $80^{*}$ & 0.448 \\
\hline ТВC02 & & & & ТВC01 & $95^{*}$ & 0.448 \\
\hline $\mathrm{TBC} 03$ & $\mathrm{TBC} 07$ & $95^{*}$ & 0.036 & & & \\
\hline TBC05 & ТВС07 & 80 & 0.437 & & & \\
\hline ТВC17 & ТВС07 & $80^{*}$ & 0.198 & ТВС05 & $80^{*}$ & 0.331 \\
\hline $\mathrm{TBC} 21$ & ТВC30 & 95 & 0.500 & & & \\
\hline $\mathrm{TBC} 22$ & ТВС31 & 80 & 0.500 & & & \\
\hline ТВC24 & ТВС30 & 95 & 0.500 & & & \\
\hline $\mathrm{TBC} 25$ & ТВС30 & 95 & 0.500 & & & \\
\hline TBC26 & ТВС30 & 95 & 0.500 & & & \\
\hline TBC 28 & $\mathrm{TBC} 31$ & $80 *$ & 0.500 & TBC22 & 80 & 0.500 \\
\hline \multicolumn{7}{|l|}{ SPI } \\
\hline ТВC02 & & & & ТВС06 & $80 *$ & 0.216 \\
\hline $\mathrm{TBC} 03$ & & $95^{*}$ & 0.014 & & & \\
\hline $\mathrm{TBC} 05$ & ТВC07 & 95 & 0.451 & ТВC04 & $80 *$ & -0.014 \\
\hline ТВС06 & & & & & $80^{*}$ & 0.216 \\
\hline $\mathrm{TBC} 10$ & ТВС07 & 80 & 0.200 & ТВC02 & & \\
\hline ТВC17 & & $80 *$ & 0.198 & & $80 *$ & 0.331 \\
\hline \multicolumn{7}{|l|}{ SPII } \\
\hline TBC 21 & ТВС 30 & 95 & 0.500 & TBC 26 & 95 & 0.500 \\
\hline TBC 22 & TBC 31 & 80 & 0.500 & TBC 28 & 80 & 0.500 \\
\hline TBC 26 & TBC 30 & 95 & 0.500 & TBC 21 & 95 & 0.500 \\
\hline TBC 28 & ТВС 31 & 80 & 0.500 & ТВC 22 & 80 & 0.500 \\
\hline
\end{tabular}

*Cases where maternity or paternity were assign considering one mismatch.

mation of heterozygosity and $f$-values based on microsatellite loci because of limitations in sampling all possible genotypes at a specific locus (Hedrick 1999). In our study, a limited number $(\mathrm{n}=27)$ of $M$. tridactyla were available to be sampled, however since the number of M. tridactyla in the whole park is relatively small at about 300 animals, or 0.23 per $\mathrm{km}^{2}$, (Miranda, 2004) we sampled almost $10 \%$ of the whole $M$. tridactyla population. Based on this, we believe that the low polymorphism and high inbreeding ( $f=0.833$ for SPI, $f=0.999$ for SPII and $f=0.879$ for the overall sample) with a departure from Hardy-Weinberg equilibrium at all loci showed by the population studied are not an artifact of sample size. Over the last few decades ENP has suffered recurrent fires and $97 \%$ of its area was burned in 1994, including the central area from which the SPI subpopulation was collected. Silveira et al (1999) estimated that at least 332 giant anteaters died because of the direct action of the 1994 fire and a population of $43(0.034$ per $\mathrm{km}^{2}$ ) remained after the fire. Therefore, our data may be the outcome of a genetic bottleneck suffered by the population in 1994. Thus although a partial recovery of the popu- lation may be inferred (Miranda 2004), the current population may display low genetic diversity and high inbreeding because of the genetic bottleneck after the fire. Nevertheless, the low levels of polymorphism may be the outcome of the natural history and evolution of $M$. tridactyla, as reported for other species (e.g. Reeve et al. 1990, Baumgarten 2001, Caparroz et al. 2001).

While high values of pairwise relatedness (r) were presented by many $M$. tridactyla pairs, e.g. half $\mathrm{r}=0.25$ ) and full sibs $r=0.50$ ) or first $r=0.125$ ) and second cousins $\mathrm{r}=0.0625)$, the mean relatedness among all the animals sampled was low but significantly different from zero $r=0.095 \pm 0.002$ ), probably because of many negative values. Queller and Goodnight (1989) have pointed out that negative r-values may occur if the allele frequencies of the two individuals compared differ from the population mean in opposite directions. Although relatedness between all the SPI animals did not differ significantly from the relatedness between all the animals sampled, adult males and females in the central area of the park (SPI) were significantly more related than the other animals sampled. As discussed 
above, this result showed that mating between closed related $M$. tridactyla may be very frequent and is playing an important role in the current genetic structure of the total ENP population. Added to the possible genetic bottleneck that occurred about ten years ago, the isolation of the population may favor mating between closed related $M$. tridactyla. Although the ENP is one of the largest cerrado reserves and covers almost 140,000 ha it is surrounded by soybean and maize farms and cattle pasture. The fact that many $M$. tridactyla are run over on the roads near the park and are sometimes illegally hunted outside the park may have resulted in less migration and gene flow between the ENP and the small and rare cerrado fragments in the region, thus increasing mating between closely-related animals.

Although the small sample size may have affected the estimated F-statistic (Bailees \& Lugon-Moulin, 2002; Koskinen et al., 2004) our results indicated that alleles were not randomly distributed between and within the SPI and SPII subpopulations, since $\theta$ and $F$ were significantly different from zero (Cockerham, 1969). Because microsatellites are highly variable and subject to high mutation rates $\left(4 \mathrm{~N}_{\mathrm{e}} u>1\right)$, they usually display high levels of withinpopulation heterozygosity (Hedrick 1999). However, when alleles are identical by state statistics based on infinite allele models such as $\theta$ or $\mathrm{F}_{\mathrm{ST}}$ tend to underestimate population differentiation (Slatkin 1995; Hedrick 1999). Nevertheless, $\theta$ and $\mathrm{R}_{\mathrm{ST}}$ presented very similar values, indicating that identity-by-descent and by state have not diverged in the subpopulations studied. Additionally, the high and significant inbreeding coefficient showed that mating between close relatives may play an important role in determining the differentiation between SPI and SPII, and ultimately in the genetic structure of the M. tridactyla population at Emas National Park.

Our results showed slight evidence that $M$. tridactyla females are more phylopatric than males, with significant differences in $f$ and $A I c$ between sexes. Members of the dispersal sex may display a higher $f$-value due to the Wahlund effect caused by the admixture of animals from different populations and the genotype of the dispersal sex may be less likely to occur in a sample, hence the dispersal sex tends to have lower AIc values than the more phylopatric sex (Goudet et al. 2002). We found that SPI and SPII or SPI and all other females presented higher Aic-values and lower $f$-values when compared with males. In mammals female phylopatry is more common, although some exceptions have been described (Greenwood 1980; Johnson and Gaines 1990). Female phylopatry may be expected in species where mating system is based on mate defense by males, with females tending to return to, or remain in, the same area while males roam to find other potential mates. The giant anteater is essentially solitary but females may take care of the offspring during the early stages (six to nine months postpartum) carrying the young on her back
(Eisenberg and Redford 1999), behavior which may favor female phylopatry.

Parentage assignment can be highly affected by relatedness, and paternity can not be resolved between the true father and his sons when males related as half sibs or more to the offspring $r=0.25$ ) are among the candidate fathers and the mother is unknown (Marshall et al., 1998). Our data clearly showed this effect in that in the SPII subpopulation parentage assignment was unresolved (Table 4) with specimens TBC2 1 and TBC26 plus TBC22 and TBC $28 \mathrm{r}=0.500$ for each pairs) being indicated as both offspring and father of each other, probably because of the high relatedness between some animals in this subpopulation (such as the previously cited pairs) which suggests that they are parent-offspring or half-sibs. Nonetheless, maternity could be assigned with $95 \%$ confidence, and of the three SPII adult females two (TBC30 and TBC31) were the mothers of many offspring in the SPII subpopulation and the peripheral area of the park. Maternity at SPI could be assigned only to resident females. Nevertheless, only two cases were resolved without invoking mismatches, i.e. TBC07 and TBC05 (95\% confidence) and TBC09 and TBC10 (80\% confidence). The high homozygosity displayed by the population studied indicated a high frequency of null alleles. Nevertheless, a significant overall homozygote excess occurred, indicating that the population might not be panmictic, i.e. randomly mated (Wright 1931), and that the mismatch should be interpreted as parentage exclusion and not as null alleles.

In conclusion, our results showed that the population of M. tridactyla in Emas National Park has a low level of genetic diversity and a high level of inbreeding. Additionally, a high level of relatedness could be detected between many pairs of animals, and close related and unrelated $M$. tridactyla may have an overlapping home range. The current population genetic structure may be the outcome of the evolution and natural history of the species. The phylopatric behavior of females and their low fecundity, increased by isolation and the recurrent fire events, could have led to high population mortality and may have increased the frequency of mating between closely related animals. Although the low number of young M. tridactyla observed in the population studied (one juvenile female and one sub-adult male) may be explained by the low number of adult females $(n=7)$, this may also indicate inbreeding depression. The genetic structure and dynamics of this population needs to be more profoundly investigated in the future to provide sound information with which to design conservation strategies for M. tridactyla in the Emas National Park.

\section{Acknowledgments}

We are grateful for the support given to this work by the Whitley Laing Foundation/Rufford Small Grants, the Brazilian O Boticário Wildlife Protection Foundation (Fun- 
dação O Boticário de Proteção à Natureza, Brazil), the MacArthur Foundation, the National Center for Natural Predators Research/Brazilian Environment Institute (Centro Nacional de Pesquisas para Conservação de Predadores Naturais/IBAMA, Brazil), Conservation International/ Brazil and the Brazilian Ministry of Science and Technology $(\mathrm{CNPq})$ with a fellowship to F.H.G.R. We thank K. Ritland for help with the Mark program and T. Marshall for help with the Cervus software and J.E. Garcia for the $M$. tridactyla primer sequences. We also acknowledge the support of the IBAMA and especially Emas National Park staff for their logistical support and P.S.T. Amaral, A.C. Bezerra, V.M.G. Barros, P.A.L. Borges and J.M. Gontijo for their kind help in fieldwork.

\section{References}

Bailees F and Lugon-Moulin N (2002) The estimation of population differentiation with microsatellite markers. Molecular Ecology 11:155-165.

Baumgarten MM, Kohlrausch AB, Miyaki CY, Freitas TRO and Araújo AM. DNA fingerprinting and parentage in masked (Sula dactylatra) and brown (S. leucogaster) boobies. Ornitología Neotropical 12:319-326.

Caparroz R, Miyaki CY, Bampi MI and Wajntal A. Analysis of the genetic variability in a sample of the remaining group $\mathrm{pf}$ Spix's macaw (Cyanopsitta spxii, Psittaciformes, Aves) by DNA fingerprinting. Biological Conservation 99:307-311.

Chakravarti A and Li CC (1983) The effect of linkage on paternity calculations. In: Walker H (ed) Inclusion Probabilities in Parentage Testing. American Association of Blood Banks, Arlington, pp 411-422.

Charlesworth D and Charlesworth B (1987) Inbreeding depression and its evolutionary consequences. Ann Rev Ecol Syst 18:237-268.

Cockerham CC (1969) Variance of gene frequencies. Evolution 23:72-84.

Coltman DW, Bowne WD and Wright JM (1998) Birth weight and neonatal survival of harbour seal pups are positively correlated with genetic variation measured by microsatellites. Proceedings of the Royal Society of London B 265:803-809.

Creste S, Neto AT and Figueira A (2001) Detection of single sequence repeat polymorphisms in denaturing polyacrylamide sequencing gels by silver staining. Plant mol. Biol. Report 19:299-306.

Crnokrak P and Roff DA (1999) Inbreeding depression in the wild. Heredity 83:260-270.

Dietz JM, Baker AJ and Ballou JD (2000) Demographic evidence of inbreeding depression in wild golden lion tamarins. In: Young AG and Clarke GM (eds) Genetics, Demography and Viability of Fragmented Populations. Cambridge University Press, Cambridge, pp 203-211.

Darwin CR (1876) The Effects of Cross and Self Fertilization in the Vegetable Kingdom. John Murray, London.

Eldridge MDB, King JMA, Loupis K, Spencer PBS, Taylor AC, Pope LC and Hall GP (1999) Unprecedented low levels of genetic variation and inbreeding depression in an island population of the black-footed rock-wallaby. Conservation Biology 13:531-541.
Eisenberg JF and Redford KH (1999) Mammals of the Neotropics. v. 3. The Central Neotropics: Ecuador, Peru, Bolivia, Brazil. University of Chicago Press, Chicago, 609 pp.

Frankham R (1995) Conservation genetics. Ann. Rev. Genet. 29:305-327.

Frankham R (2003) Genetics and conservation biology. Comptes Rendus Biologies 326:22-29.

Frankham R, Ballou JD and Briscoe DA (2002) Introduction to Conservation Genetics. Cambridge University Press, Cambridge, UK, $617 \mathrm{pp}$.

Garcia JE, Vilas Boas LA, Lemos MVF, Lemos EGM and Contel EPB (2005) Identification of microsatellite DNA markers for the giant anteater Myrmecophaga tridactyla. Journal of Heredity 96:600-602.

Gilpin ME and Soulé ME (1986) Minimum viable populations: Process of species extinction in conservation biology the science of scarcity and diversity. In: Soulé ME (ed) Conservation Biology: The Science of Scarcity and Diversity. Sinauer, Sunderlands, pp 19-34.

Goldstein DB and Schlotterer C (1999) Microsatellites Evolution and Applications. Oxford University Press, Oxford, UK, 368 pp.

Goodman SJ (1997) $R_{\mathrm{ST}}$ Calc: A collection of computer programs for calculating estimates of genetic differentiation from microsatellite data and determining their significance. Molecular Ecology 6:881-885.

Goudet J (2002) FSTAT 2.9.3.2, a program to estimate and test gene diversities and fixation indices. Available from http://www.unil.ch/izea/softwares/fstat.html.

Goudet J, Raymond M, Demeeus T and Rousset F (1996) Testing differentiation in diploid populations. Genetics 144:19331940.

Goudet J, Perin N and Waser P (2002) Tests for sex-biased dispersal bi-parentally inherited genetic markers. Mol Ecol 11:1103-1114.

Greenwood PJ (1980) Mating systems, philopatry and dispersal in birds and mammals. Animal Behaviour 28:1140-1162.

Hedrick PW (1999) Highly variable loci and their interpretation in evolution and conservation. Evolution 53:313-318.

IUCN International Union for Conservation of Nature and Natural Resources (2004) The IUCN Mammal Red Data Book, Part 1. IUCN, Gland.

Johnson ML and Gaines MS (990) Evolution of dispersal: Theoretical models and empirical tests using birds and mammals. Ann Rev Ecol Syst 21:449-480.

Koskinen MT, Hirvonen H, Landry PA and Primmer CR (2004) The benefits of increasing the number of microsatellites utilized in genetic population studies: An empirical perpective. Hereditas 141:61-67.

Laurance WF and Bierregaard RO (eds) (1997) Tropical Forest Remnants. Chicago University Press, Chicago, 616 pp.

Lynch M and Ritland K (1999) Estimation of pairwise relatedness with molecular markers. Genetics 152:1753-1766

Marshall TC (2001) Cervus 2.0. Available from http://helios.bto. ed.ac.uk/evolgen.

Marshall TC, Slate J, Kruuk LEB and Pemberton M (1998) Statistical confidence for likelihood-based paternity inference in natural populations. Mol Ecol 7:639-655.

Miranda GHB (2004) Ecologia e Conservação do TamanduáBandeira (Myrmecophaga tridactyla, Linnaeus, 1758) no 
Parque Nacional das Emas. Tese de Doutorado, Universidade de Brasília, Brasília.

Nei M (1978) Estimation of average heterozygosity and genetic distance from a small number of individual. Genetics 89:583-590.

Nowak RM (1999) Walker's Mammals of the World. 6th ed. Johns Hopkins University Press, Baltimore, 836 pp.

Paetkau D, Calvert W, Stirling I and Strobeck C (1995) Microsatellite analysis of population structure in Canadian polar bears. Mol Ecol 4:347-354

Queller DC and Goodnight KF (1989) Estimating relatedness using genetic markers. Evolution 43:258-275.

Ralls K, Hervey PH and Lyles AM (1986) Inbreeding in natural populations of birds and mammals. In:. Soulé ME (ed) Conservation Biology: The Science of Scarcity and Diversity. Sinauer, Sunderland, pp 35-56.

Ralls K, Ballou JD and Templeton A (1988) Estimates of lethal equivalents and the cost of inbreeding in mammals. Conservation Biology 2:185-193.

Ratter JA, Ribeiro JF and Bridgewater S (1997) The Brazilian Cerrado vegetation and threats to its biodiversity. Annals of Botany 80:223-230.

Reed DH (2005) Relationship between population size and fitness. Conservation Biology 19:563-568.

Reed DH and Frankham R (2003) Correlation between fitness and genetic diversity. Conservation Biology 17:230-237.

Reed DH, Lowe E, Briscoe DA and Frankham R (2003) Inbreeding and extinction: effects of rate of inbreeding. Conservation Genetics 4:405-410.

Reeve HK, Westneat DF, Noon WA, Sherman PW and Aquadro CF (1990) DNA "fingerprinting" reveals high levels of inbreeding in colonies of the Eusocial Naked Mole-Rat. Proceedings of the National Academy of Sciences of the United States of America 87:2496-2500.

Ritland K (2004) Mark - Marker Inferred Relatedness and Quantitative Inheritance Program, v. 2.0. Free program distributed by the author over the internet from http://genetics. forestry.ubc.ca/ritland/programs.html.
Saccheri I, Kuussaari M, Kankare M, Vikman P, Fortelius W and Hanski I (1998) Inbreeding and extinction in a butterfly metapopulation. Nature 392:491-494.

Silveira L, Rodrigues FHG, Jacomo ATA and Diniz JAF (1999) Impact of wildfires on the megafauna of Emas National Park, Central Brazil. Oryx 33:108-114.

Slatkin M (1995) A measure of population subdivision based on microsatellite allele frequencies. Genetics 139:457-462.

Sokal RR and Rohlf J (2000) Biometry. 4th edition. W.H. Freeman, New York, 887 pp.

Terborgh J and Winter B (1980) Some causes of extinction. In: Soulé ME and Wilcox BA (eds) Conservation Biology, an Evolutionary-Ecological Perspective. Sinauer, Sunderlands, pp 119-133.

Valdes AM, Slatkin M and Freimer NB (1993) Allele frequencies at microsatellite loci: The stepwise mutation model revisited. Genetics 133:737-749.

Weir BS and Cockerham CC (1984) Estimating F-statistics for the analysis of population structure. Evolution 38:1358-1370.

Westemeier RL, Brawn JD, Simpson SA, Esker TL, Jansen RW, Walk JW, Kershner EL, Bouzart JL and Paige KN (1998) Tracking the long-term decline and recovery of an isolated population. Science 282:1695-1698.

World Conservation Union-IUCN (2004) 2004 IUCN Red List of Threatened Species. Available from www.redlist.org.

Wright S (1917) Coefficients of inbreeding and relationship. American Naturalist 51:545-559.

Wright S (1921) System of mating II: The effects of inbreeding on the genetic composition of a population. Genetics 6:124143.

Wright S (1931) Evolution in mendelian population. Genetics 16:97-159.

Wright S (1937) The distribution of gene frequencies in population. Proceedings of the Natural Academy of Science of USA 23:307-320.

Wright S (1946) Isolation by distance under diverse systems of mating. Genetics 31:39-59.

Wright S (1951) The genetical structure of populations. Annual Eugenics 15:323-354.

Wright S (1965) The interpretation of population structure by F-statistics with special regard to system of mating. Evolution 19:395-420.

Associate Editor: Louis Bernard Klaczko 